\title{
Outside Medicine
}

Sir Charles Scarburgh was an important person in his own day because he was a great practising doctor and physician to Charles II, to James II, and to William and Mary. Even in that respect he has a place in history, because he was so generally respected that it was his word, after he had been chief physician at the death-bed of Charles II, which exonerated James II from the widely-held suspicion that he had poisoned his brother. But he was lastingly important for three reasons: his influence on mathematics, his influence on the Royal Society, and as the collector of a great library.

He came of a Norfolk family, at North Walsham, where the remains of the house ultimately became a girls' school, but he was born in London, where he was left behind when his father emigrated to America to found a family there. This domestic disintegration did not, in those days, lead the boy to turn into a juvenile delinquent. On the contrary, he did well at St. Paul's School and proceeded to Caius College in 1634, where he held a scholarship until 1640, when he was made a Fellow. He worked at mathematics with Seth Ward (the future Bishop of Salisbury), of Emmanuel College, Cambridge, where, incidentally, John Wallis, a greater mathematician than either, ${ }^{*}$ was an undergraduate at the same time. Scarburgh and Ward had difficulty with William Oughtred's Clavis Mathematica, which was not very surprising, for it is one of those books written without the least concession to the reader. So they went to visit the author at Aldbury in Surrey, where he was vicar. Oughtred was a great mathematician, the link between Napier at the beginning of the seventeenth century and Wallis and Newton at the end of it. He invented the straight slide-rule and the sign " $x$ " for multiplication, and a good deal more. He liked the young men, and kept them with him until he had explained his book to them. He thought Scarburgh a man with a remarkably retentive memory, a most acute and penetrating observer, and a modest and unassuming companion. ${ }^{1}$ On his return to Cambridge, Scarburgh was the first person to lecture on the Clavis Mathematica, which became the standard textbook in the university. He later made an English translation of Euclid, which was published in 1703 after his death by his son as The English Euclid, being the First Six Elements of Geometry.

\section{Trouble with Roundheads}

Scarburgh lost his fellowship and his library in 1640, when the Roundheads reorganized Cambridge. He went to Oxford, to Merton, where Harvey was warden, and took up medicine.

*But not in Pepys's estimation, so interesting a person: “16th Dec. 1666. With Bruncker to Sir Peter Neil's chamber. Here also Dr. Wallis, the famous scholar and mathematician, but he promises little." For Scarburgh see Pepys's Diary for 24 May 1610 and 27 February 1663.

Royal College of Physicians, London NW1 4LE

C. NEWMAN, M.D., F.R.C.P., Harveian Librarian

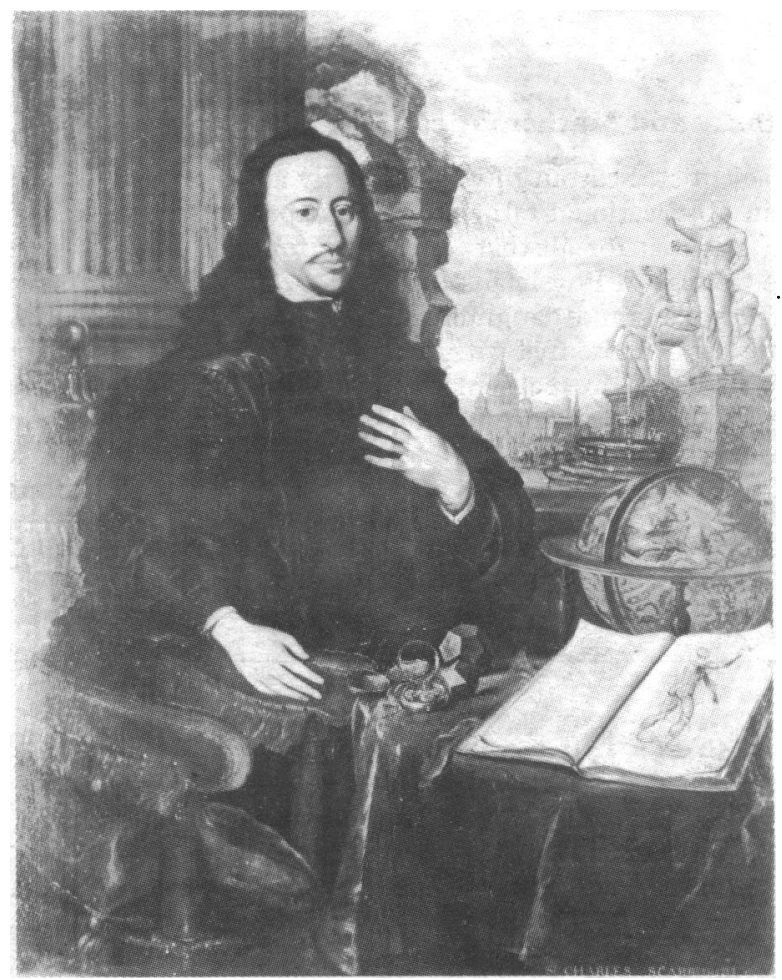

Sir Charles Scarburgh. Reproduced by permission of the Royal College of Physicians of London.

Becoming one of Harvey's protégés, he helped him with work for the De Generatione, doing a large number of dissections of animals, though his principal interest was in the mathematical analysis of muscular motion, of which he was the pioneer. He took the Oxford D.M. in 1646. Royalist Oxford fell in that year to Cromwell's forces. The royalist doctors had already for the most part left the town, but Scarburgh stayed with the King's army until 1648, when Harvey wrote to him, "Prithee leave off gunning and stay here [London], I will bring thee into practice." Scarburgh was admitted to the Royal College of Physicians in 1648, and made a Fellow in 1650.

The return of the doctors from Oxford brought together again the group which had before the war been discussing scientific matters at the College of Physicians and associated them with the similar discussions at Gresham College. Dr. C. Webster ${ }^{2}$ has described how reading Walter Charleton's improbable book on The Immortality of the Soul revealed the importance of the discussions at the College of Physicians on the origin of the Royal Society. The "veritable Solomon's House" of the Immortality parallels the "Invisible College" of Boyle's descriptions of the discussions at Gresham College. These two streams led directly to the foundation of the Royal Society. It is interesting that the original plan was for the Royal Society 
to meet in the new Museum Harveianum at the College of Physicians at Amen Corner, and this, combined with the weight of the medical original members, might have directed the interests of the new society towards the biological sciences. The college, however, had not been founded for any such purpose, and the scheme was abandoned; and Scarburgh and the other doctors, such as Merrett and Charleton, with more general scientific interests, joined with those at Gresham of like opinions to direct the attention of the Royal Society to the mathematical and physical sciences, which were ripe for development, which the biological sciences were not. This was one of the three things which established the success of the new society. The other two were the determination of Oldenberg, the first secretary, to exclude all curiosities and marvels in favour of straight experimental science, and the brilliance of Hooke's practical demonstrations.

\section{Anatomy and Mathematics}

As a scientist, Scarburgh was primarily an anatomist-that is to say, an observational rather than an experimental scientist, but a real scientist for all that, observing for himself. The portrait at the College of Physicians, which came from Temple Newsam (Scarburgh's grand-daughter married Lord Ingram), represents his interest in anatomy by its inclusion of an anatomical textbook, and his interest in mathematics by the Platonic solids and the globe on the table-and possibly by the Roman architecture in the background. Architecture was classed with the mathematical sciences, but Scarburgh was never in Rome, and the architecture may be there only because it corresponds with the Glasgow portrait of Harvey. The two pictures were probably painted together as a symbol of the friendship of the two men, and that is just as likely an explanation of the Roman background.

Scarburgh's interest in mathematics lasted all his life and was responsible for the collection of his magnificent library, so good that he intended it for the nation. The only way of bringing this about in those days was to leave it to the Royal Library. Evelyn told the story concisely in his diary for 10 March 1695: "I dined at the Earl of Sunderland's with Lord Spencer. My Lord showed me his library, now again improved by many books bought at the sale of Sir Charles Scarburgh ... which was the very best collection, especially of mathematical books, that was, I believe in Europe; once designed for the King's Library at St. James's; but the Queen dying, who was the great patroness of that design, it was left fall, and the books miserably dissipated." Queen Mary was the intellecutually interested one of the pair: William III was interested only in frustrating Louis XIV.

To what extent the library was "dissipated" is uncertain. Spencer's library was not the one which went to the John Rylands Library in 1892, but was, Dr. Margaret Wright, ${ }^{3}$ of that library, tells me, mortgaged to the Duke of Marlborough while it was at Sunderland House in Piccadilly and taken to Blenheim. Thence it was sold by George, the eighth duke, at Puttick and Simpson's in 1881-3. The sale-catalogues in the British Museum show that it was a splendid library indeed but that, as a comparison of it with the catalogue of Scarburgh's library shows, it did not at that time contain Scarburgh's books. It would be interesting to know what did happen to them.

\section{Refrences}

1 Keevil, J. J., Annals of Science, 1952, 8, 113.

2 Webster, C., Bulletin of the History of Medicine, 1967, 41, 393.

${ }^{3}$ Wright, M. M., personal communication.

\section{We publish below a selection \\ Smoking and Mental Disease}

Does smoking cause or aggravate mental disease such as schizophrenia, manic depressive psychosis, melancholia, paranoia, neurasthenia, or hysteria?

There is certainly no evidence whatsoever that smoking causes mental illness or neurosis. Furthermore, there is no evidence even of an association, except with other addictions. In some cases nicotine intoxication from heavy smoking may give rise to symptoms found in anxiety states-for example, restlessness, tachycardia, and cold fingers and toes. But claims that smokers tend to be more tense, anxious, emotional, and neurotic have not been generally substantiated. ${ }^{2}$ Nor are people suffering from psychiatric disorders any more likely to be smokers or to smoke more heavily than matched psychiatrically normal controls. ${ }^{3}$ There is, however, an association between smoking and normal drinking ${ }^{4}$ and alcoholism. A study of psychiatric outpatients showed that $92 \%$ of alcoholics were smokers compared with $50 \%$ of neurotics attending the same hospital. Some $96 \%$ of heroin users attending addiction clinics in London are smokers, compared with $58 \%$ of the general population.? There is a similar, strong statistical association between smoking and cannabis use, ${ }^{8}$ analgesic abuse, ${ }^{9}$ and general use of all manner of drugs and medicines including laxatives, tranquillizers, sleeping pills, stimulants, and slimming pills. ${ }^{10}$ But there is no evidence from these associations that smoking causes these disorders.
There have been claims that anti-smoking campaigns have made addicted smokers excessively guilty, even to the extent of mental breakdown on attempting to stop smoking. ${ }^{11}$ Evidence for this is scanty, however, and at present no more than anecdotal. Other studies have suggested the reverse: $66 \%$ of successful ex-smokers and $56 \%$ of those who relapsed said that stopping smoking had not been difficult at all. ${ }^{4}$ A sample of British doctors who stopped smoking successfully suffered no more from minor mental symptoms than doctors who continued to smoke. ${ }^{12}$ Indeed, the successful ex-smokers were more aware of the benefits than any sense of deprivation, as were a sample of 222 M:lbourne ex-smokers. ${ }^{13}$

1 Eysenck, H. J., Fournal of Psychosomatic Research, 1963, 7, 107.

2 Smith, G. M., in Learning Mechanisms in Smoking. Ed. W. A. Hunt, p. 42. Chicago, Aldine Publishing Company, 1970.

3 Eastwood, M. R., and Trevelyan, M. H., Lancet, 1971, 1, 107.

4 McKennell, A. C., and Thomas, R. 'K., "Adults' and Adolescents' Smoking Habits and Attitudes," Government Social Survey London, H.M.S.O., 1967.

5 Orford, J., Waller, S., and Peto, J., Quarterly fournal of Studies on Alcohol, $1974,35,1316$.

- Dreher, K. F., and Fraser, J. G., International fournal of the Addictions, $1968,3,65$.

${ }^{7}$ Blumberg, H. H., et al., International fournal of the Addictions, 1974, 9, 1. Kosviner, A., Hawks, D. V., and Webb, M. G. T., British fournal of Addiction, $1973,69,35$.

'Murray, R. M., British fournal of Psychiatry, 1973, 123, 99.

10 Seltzer, C. C., Friedman, G. D., and Siegelaub, A. B., American fournal of Public Health, 1979, 64, 466.

11 Tamerin, J. S., and Neuman, C. P., Comprehensive Psychiatry, 1973, 14, 35. 12 Fletcher, C., and Doll, R., British fournal of Preventive and Social Medicine, $1969,23,145$.

13 Trahair, R. C. S., Medical fournal of Australia, 1967, 1, 929. 